\title{
PENINGKATAN MOTIVASI DAN HASIL BELAJAR SEJARAH KEBUDAYAAN ISLAM (SKI) KELAS XI IPS 1 MAN 1 CILACAP MELALUI MODEL KOOPERATIF JIGSAW
}

\author{
MUSLIHUDDIN \\ MAN 1 Cilacap Jawa Tengah \\ Muslihudin.solehudin@gmail.com
}

\begin{abstract}
ABSTRAK
Penelitian ini bertujuan untuk mengetahui penggunaan model kooperatif jigsaw untuk meningkatkan motivasi dan hasil belajar siswa pada bidang studi Sejarah Kebudayaan Islam (SKI) kelas XI IPS 1 MAN 1 Cilacap. Metode penelitian mengguakan pendekatan Penelitian Tindakan Kelas dengan dua siklus. Hasil penelitian menunjukkan bahwa proses pembelajaran menggunakan model Kooperatif Jigsaw dari kondisi awal, siklus 1, dan siklus 2 motivasi dan hasil belajar siswa terus mengalami peningkatan, sebagai berikut: (1) Motivasi dengan kategori rendah mengalami penurunan yaitu dari $71,88 \%$ menjadi 38,54 , sehingga pada siklus 1 ke siklus 2 dari 38,54\% menjadi $0 \%$; Motivasi dengan kategori sedang dari kondisi awal ke siklus 1 yaitu $21,88 \%$ menjadi $37,50 \%$, sehingga pada siklus 1 ke siklus 2 yaitu dari 37,50\% menjadi 13,54 \%; dan motivasi dengan kategori tinggi dari kondisi awal ke siklus 1 yaitu dari 6,25\% menjadi 23,96\%, sehingga pada siklus 1 ke siklus 2 yaitu dari 23,96\% menjadi 86,46\%. (2) Hasil belajar mengalami kenaikan yaitu dari 71,88 \% menjadi 46,88 \%, sehingga pada siklus 1 ke siklus 2 dari 46,88 \% menjadi 12,50\%. Yang nilainya tuntas (=/> KKM) pada kondisi awal ke siklus 1 yaitu dari $28,12 \%$ menjadi $53,12 \%$, pada siklus 1 ke siklus 2 yaitu dari $53,12 \%$ menjadi 87,50 \%. Bedasarkan prosentase tersebut menunjukkan bahwa pembelajaran dengan menggunakan model Jigsaw dapat meningkatkan motivasi dan hasil belajar siswa dengan masing-masing nilai $100 \%$ dan $87.50 \%$
\end{abstract}

Kata kunci: Motivasi belajar, Hasil Belajar, dan Kooperatif Jigsaw

\section{PENDAHULUAN}

Sinergi antara pendidik sebagai fasiltator dengan siswa sangat menentukan keberhasilan proses belajar mengajar. Akan tetapi pada kenyataan yang dihadapi sering seorang pendidik khususnya penulis sebagai pendidik mata pelajaran SKI merasa bahwa materi pelajaran yang disampaikan kurang mendapat respon dari siswa, dan pada ujungnya hasil belajar pun kurang maksimal. Berdasarkan observasi dan analisis hasil ulangan harian pada KD I diketahui bahwa motivasi dan hasil belajar siswa MAN Negeri 1 Cilacap Kelas XI IPS 1 dalam mapel Sejarah Kebudayaan Islam (SKI) adalah rendah. Hasil observasi awal yang dilakukan penulis menunjukkan fakta sebagai berikut: Siswa yang motivasinya rendah $71,88 \%$, yang motivasinya sedang $21,88 \%$, dan yang motivasinya tinggi hanya $6,25 \%$. Sedangkan siswa yang memperoleh nilai di bawah KKM sebanyak 71,88\%, Siswa yang memperoleh nilai sama dengan KKM sekitar 21,88\%, dan siswa yang memperoleh nilai di atas KKM hanya $6,25 \%$. Harapan penulis sebagai pendidik, hasil belajar siswa dalam mata pelajaran SKI setidaknya minimal $84,38 \%$ siswa mencapai nilai di atas KKM (=/>KKM). Adapun untuk motivasi siswa yang diharapkan adalah mencapai $100 \%$. Rendahnya motivasi dan hasil belajar siswa kelas XI IPS 1 pada mata pelajaran SKI menurut pandangan penulis adalah disebabkan oleh beberapa faktor, antara lain strategi atau metode pembelajaran yang digunakan pendidik masih monoton, siswa tidak diberikan kesempatan untuk aktif dan melakukan banyak kegiatan dan latihan merupakan faktor-faktor penting yang menyebabkan motivasi dan hasil belajar siswa pada mapel SKI kelas XI IPS 1 MAN Negeri 1 Cilacap rendah.

Dari analisis penyebab masalah, maka upaya yang diperkirakan dapat meningkatkan motivasi dan hasil belajar siswa MAN Negeri 1 Cilacap dalam mapel Sejarah Kebudayaan Islam khususnya kls XI IPS 1 adalah penerapan model yang tepat, yakni model pembelajaran yang memberi kesempatan kepada siswa untuk melakukan diskusi, latihan dan pembimbingan 
langsung pendidik sehingga pada endingnya siswa memiliki kemampuan dalam menyelesaikan soal-soal Sejarah Kebudayaan Islam. Model yang diduga tepat yakni model Kooperatif Jigsaw. Hal ini senada dengan hasil penelitian Sinring, Risda (2018) bahwa: (1) Penggunaan Metode Jigsaw dapat meningkatkan motivasi belajar siswa pada mata pelajaran Sejarah Kebudayaan Islam, (2) Dengan membandingkan besarnya t yang diperoleh dalam perhitungan yang tercantum pada nilai $t$ hitung maka dapat diketahui bahwa thitung lebih besar daripada t tabel ( $\mathrm{t}$ hitung $\geq \mathrm{t}$ tabel) dimana $\mathrm{t}$ hitung $=353,38$ sedangkan $\mathrm{t}$ tabel $=2,074$. (3) Dengan $\mathrm{t}$ hitung $\geq$ t tabel maka hipotesis dapat diterima dan ini berarti Efektivitas Metode Jigsaw dapat Meningkatkan Motivasi Belajar Sejarah Kebudayaan Islam Siswa di Kelas VIII MTs Darul Ulum Ath-Thahiriyah Paladang Kabupaten Pinrang. Meurut Luthfiyah, U. (2018) mengemukakan bahwa fenomena penerapan model pembelajaran cooperative learning tipe jigsaw untuk meningkatkan hasil belajar siswa sangat perlu dikembangkan dan ditingkatkan pada siswa. Meningkatkan hasil belajar dapat membantu keberhasilan pembelajaran Sejarah Kebudayaan Islam (SKI) di MI NU Tarbiyatus Shibyan Jetak Kedungdowo Kaliwungu Kudus. Kurniasih, N. F. (2020) Model pembelajara Jigsaw merupakan model pembelajaran yang menarik dan menyenangkan dalam belajar Sejarah Kebudayaan Islam.

Dalam buku Kementerian Pendidikan Dan Kebudayaan Direktorat Jenderal Pendidikan Dasar Dan Menengah Direktorat Pembinaan Sekolah Menengah Pertama (2016) dijelaskan tentang Proses pembelajaran dengan menggunakan model Kooperatif Jigsaw adalah sebagai berikut: (1) Pembentukan kelompok, (2) Pembelajaran pada kelompok asal, (3) Pembentukan kelompok aAhli, (4) Diskusi kelompok ahli, (5) Diskusi kelompok asal (Induk), (6) Diskusi kelas, (7) Pemberian kuis, (8) Pemberian penghargaan kelompok. Syarifuddin, A. (2011) mengatakan pembelajaran cooperative learning tipe jigsaw adalah model pembelajaran dengan menggunakan pengkelompokkan/tim kecil yang terdiri antara empat, enam, bahkan sampai delapan orang yang mempunyai latar belakang yang berbeda. Dan sistem penilaian dilakukan terhadap kelompok dan setiap kelompok akan memperoleh penghargaan, jika kelompok dapat menunjukkan prestasi yang persyaratkan. Suprihatin, S. (2017) berpendapat bahwa keuntungan kerja kelompok, yaitu: a) Dapat mengurangi rasa kantuk dibanding belajar sendiri, b) Dapat merangsang motivasi belajar, c) Ada tempat bertanya, d) Kesempatan melakukan resitasi oral, e) Dapat membantu timbulnya asosiasi dengan peristiwa lain yang mudah diingat. Adapun kekurangan kerja kelompok, yaitu: a) Bisa menjadi tempat mengobrol atau gosip, b) Sering terjadi debat sepele di dalam kelompok, bisa terjadi kesalahan kelompok. Berdasarkan diskripsi di atas, maka tujuan dari penelitian tindakan kelas ini adalah untuk mengetahui peningkatan motivasi dan hasil belajar siswa MAN 1 Cilacap kelas XI IPS 1 dalam mapel Sejarah Kebudayaan Islam (SKI) melalui penerapan model pembelajaran Kooperatif Jigsaw.

\section{METODE PENELITIAN}

Penelitian Tindakan Kelas (PTK) ini dilaksanakan dalam bentuk proses pengkajian berdaur 4 tahap, yaitu (1) merencanakan, (2) melakukan tindakan, (3) mengamati (observasi), dan (4) merefleksi, dan dilakukan dalam dua siklus. Setiap siklus dilakukan tiga kali pertemuan, dilakukan kurang lebih selama dua bulan (termasuk di dalamnya pembuatan proposal sampai pembuatan laporan). Dibawah ini uraian prosedur penelitin dari keempat kegiatan PTK.

Siklus 1. a) Perencanaan tindakan (plan) siklus 1. Pada tahap ini peneliti melakukan kegiatan-kegiatan sebagai berikut: (1) Menetapkan KD yang (sesuai waktu/kalender akademik), (2) Menetapkan indikator pencapaian, (3) Menetapkan masalah yang akan ditingkatkan, yakni "motivasi dan hasil belajar", (4) Menetapkan model pembelajaran yang akan digunakan, yaitu model Kooperatif jigsaw, 5) Menyusun rencana pembelajaran dengan menggunakan model Kooperatif Jigsaw untuk dua kali pertemuan, 6) Membuat instrumen untuk memperoleh data, yakni dengan menggunakan tes dan teknik penilaian lainnya sesuai indikator yang akan dicapai. 7) Menetapkan rekan sebagai observer/kolaborator untuk membantu melakukan observasi selama proses pembelajaran. b) Pelaksanaan tindakan (Action) siklus1, Pada tahap ini, peneliti melaksanakan kegiatan yang telah direncanakan dalam 
perencanaan tindakan. Terutama proses pembelajaran dengan berpedoman pada Rencana Pelaksanaan Pembelajaran (RPP) yang telah dibuat. c) Pengamatan (Observasi) siklus 1, Pada tahap ini, ketika peneliti melaksanakan kegiatan pembelajaran, peneliti dan dibantu oleh beberapa teman sejawat (observer/kolaborator) melakukan kegiatan pengamatan. Adapun yang dijadikan objek pengamatan adalah proses pelaksanaan pembelajaran, dan perilaku siswa selama mengikuti proses pembelajaran. d) Diskusi refleksi siklus 1. Setelah peneliti dan teman sejawat telah memperoleh data berupa pelaksanaan pembelajaran di kelas, perilaku siswa selama mengikuti pembelajaran dan hasil evaluasi untuk mengetahui kompetensi akademik siswa, maka peneliti dan teman sejawat melakukan diskusi refleksi. Kegiatan ini dimaksudkan untuk mengetahui kelemahan-kelemahan dalam pelaksanaan pembelajaran dan memberikan solusi untuk perbaikan pada siklus berikutnya.

Siklus 2. a) Perencanaan tindakan (Plan) siklus 2, Pada tahap ini peneliti melakukan kegiatan-kegiatanberikut ini: 1) Menetapkan SK/KD yang (sesuai waktu/kalender akademik), 2) Menetapkan indikator pencapaian. 3) Menyusun rencana pembelajaran dengan menggunakan model Kooperatif Jigsaw untuk dua kali pertemuan, dengan melakukan perbaikan-perbaikan dengan berdasar pada hasil diskusi refleksi siklus 1. b) Pelaksanaan tindakan (Action) siklus 2. Pada tahap ini, peneliti melaksanakan kegiatan yang telah direncanakan di perencanaan tindakan yang sudah diperbaiki berdasar pada refleksi siklus satu. c) Pengamatan (Observasi) siklus 2. Pada tahap ini, ketika peneliti melaksanakan kegiatan pembelajaran, peneliti dan dibantu oleh beberapa teman sejawat (observer/kolaborator) melakukan kegiatan pengamatan. Adapun yang dijadikan objek pengamatan adalah proses pelaksanaan pembelajaran, dan perilaku siswa selama mengikuti proses pembelajaran. d) Diskusi refleksi siklus 2. Setelah peneliti dan teman sejawat memperoleh data berupa pelaksanaan pembelajaran di kelas, perilaku siswa selama mengikuti pembelajaran dan hasil evaluasi untuk mengetahui kompetensi akademik siswa pada siklus kedua, maka peneliti dan teman sejawat melakukan diskusi refleksi Kegiatan dan mendokumenkan hasil penelitian, karena penelitian ini diproyeksikan hanya dalam dua siklus.

\section{HASIL DAN PEMBAHASAN \\ Perencanaan Tindakana Siklus I}

Rencana tindakan pada siklus 1 untuk memperbaiki motivasi dan hasil belajar siswa dibuat Rencana Pelaksanaan Pembelajaran (RPP) untuk tiga kali pertemuan (RPP lengkap terlampir). RPP dikembangkan dengan menggunakan model pembelajaran Kooperatif Jigsaw sesuai dengan langkah-langkah yang dibahas dalam kajian teori. Rencana Kompetensi Dasar yang akan diajarkan dalam RPP ini adalah KD.2. RPP ini akan diimplementasikan pada pertemuan pertama, kedua dan ketiga, yakni hari sabtu, tanggal 14, 21, 28 Maret, tahun 2020.

Adapun langkah-langkah pembelajaran yang direncanakan (secara detail tertuang dalam RPP) adalah sebagai berikut: 1) Menetapkan isi pembelajaran, 2) Meninjau ulang pembelajaran sebelumnya, 3) Menetapkan tujuan pembelajaran, 4) Menetapkan langkah-langkah pembelajaran, 5) Menjelaskan/memeragakan konsep/keterampilan baru, 6) Mengevaluasi tingkat unjuk kerja siswa, 7) Menggunakan media, alat peraga untuk menjelaskan tugas, 8) Pendidik memberikan contoh langkah-langkah penting dalam menyelesaikan tugas/soal, 9) Pendidik memberikan pertanyaan pada siswa, 10) Pendidik memberikan umpan balik (yang bersifat korektif) atas kesalahan siswa dan mendorongnya untuk menjawab dengan benar setiap tugas yang diberikan, 11) Pendidik memberikan tugas, 12) Pendidik mengawasi semua siswa secara merata, 13) Pendidik memberikan umpan balik, memuji, dan sebagainya, 14) Pendidik memberi tugas mandiri, 15) Pendidik memeriksa dan jika perlu memberikan umpan balik atas hasil kerja siswa, 16) Pendidik memberikan beberapa tugas mandiri sebagai alat untuk meningkatkan retensi siswa

\section{Pelaksanaan Tindakan siklus 1}

Berdasarkan hasil observasi yang dilakukan oleh tiga observer (teman sejawat), dengan menggunakan lembar observasi dalam tiga kali pertemuan, yakni pertemuan pertama hari sabtu, 
tanggal 13 Maret tahun 2021, pertemuan kedua pada hari Sabtu, tanggal 20 Maret tahun 2021, pertemuan ketiga pada hari Sabtu, tanggal 27 Maret tahun 2021, ditemukan bahwa proses pembelajaran berlangsung sebagai berikut: Pertemuan pertama, Secara umum sudah sesuai dengan rencana tindakan (RPP pertemuan 1). Berdasarkan observasi dan hasil analisisdata diketahui bahwa ada beberapa langkah pembelajaran yang tidak dilakukan secara optimal, yakni sebagai berikut: 1) Media, alat peraga yang digunakan dalam proses pembelajaran belum optimal, karena belum memperkuat penjelasan tentang tugas yang dilakukan siswa. 2) Optimalisasi setiap langkah pembelajaran harus dilakukan lagi 3) Langkah "mengevaluasi tingkat unjuk kerja, memberikan contoh lankah-langkah penting dalam menyelesaikan tugas, memberikan umpan balik, dan memeriksa dan memberikan umpan balik hasil kerja siswa harus diperbaiki lagi. Pertemuan kedua, Secara Secara umum pelaksanaan pembelajaran pada pertemuan kedua ini sudah sesuai dengan rencana tindakan (RPP pertemuan kedua). Berdasarkan observasi diketahui bahwa ada beberapa langkah yang belum dilakukan secara optimal. Tetapi relatif lebih baik dibanding pada pertemuan pertama, yakni: 1) Media yang digunakan dalam proses pembelajaran belum optimal, karena belum memperkuat penjelasan tentang tugas yang dilakukan siswa, 2) Optimalisasi setiap langkah pembelajaran harus dilakukan lagi, 3) Langkah "mengevaluasi tingkat unjuk kerja, memerikasa dan memberikan umpan balik hasil kerja siswa harus diperbaiki lagi. Pertemuan ketiga, Secara umum pelaksanaan pembelajaran pada pertemuan ketiga ini sudah sesuai rencana tindakan (RPP pertemuan ketiga). Pada pertemuan ketiga ini, masih sama dengan pada pertemuan pertama dan kedua. Kekurangannya juga relatif masih sama dengan pada pertemuan satu dan dua.

\section{Hasil Penelitian dan Refleksi siklus 1 Motivasi}

Menurut observer 1 didapatkan data bahwa, persentase siswa yang memiliki motivasi rendah ada $37,50 \%$, sedang ada 37,50\%, dan tinggi $25 \%$. Menurut observer 2 didapatkan data bahwa persentase siswa yang memiliki motivasi rendah ada 40,625\%, sedang 34,375\% dan tinggi $25 \%$. Menurut observer 3 didapatkan data bahwa persentase siswa yang memiliki motivasi rendah ada $37,50 \%$, sedang $40,625 \%$, dan tinggi $21,875 \%$. Kalau dirata-rata dari tiga observer tersebut diperoleh data bahwa persentase siswa yang motivasinya rendah ada 38,54\%, sedang $37,50 \%$ dan tinggi $23,96 \%$. Kalau dibandingkan dengan motivasi siswa pada kondisi awal adalah sebagai berikut:

Tebel 1. Motivasi Siswa Kondisi Awal dan Siklus 1

\begin{tabular}{|l|l|r|r|r|}
\hline No. & $\begin{array}{c}\text { Kategori } \\
\text { Motivasi }\end{array}$ & $\begin{array}{c}\text { Kondisi Awal } \\
(\mathbf{\%})\end{array}$ & $\begin{array}{c}\text { Siklus 1 } \\
(\mathbf{\%})\end{array}$ & $\begin{array}{c}\text { Siklus 2 } \\
(\mathbf{\%})\end{array}$ \\
\hline 1 & Tinggi & 6,25 & 23,96 & \\
\hline 2 & Sedan & 21,88 & 37,50 & \\
\hline 3 & Rendah & 71,88 & 38,54 & \\
\hline
\end{tabular}

Tabel 1 di atas menunjukkan bahwa motivasi siswa pada siklus 1 mengalami peningkatan. Tetapi PTK belum dikatakan berhasil, karena indikator yang ditetapkan adalah jika persentase siswa yang motivasinya dengan kategori rendah mencapai $0 \%$.

\section{Hasil Belajar}

Berdasarkan tes yang dilakukan di akhir siklus 1 diketahui bahwa rata-rata nilai yang diperoleh siswa untuk mapel SKI KD 1 (KKM 68) adalah 68. Kalau dipersentase berdasarkan kategori belum tuntas $(<\mathrm{KKM})$ dan tuntas $(=/>\mathrm{KKM})$ adalah sebagai berikut: Persentase Belum Tuntas: $15 / 32 \times 100 \%=46,875 \%$, Persentase Sudah Tuntas: $17 / 32 \times 100 \%=53,125.5 \%$. Apabila dibandingkan dengan hasil belajar siswa pada kondisi awal, hasil belajar pada siklus 1 ini mengalami peningkatan. Dapat dilihat pada tabel berikut.

\section{Tabel 2. Hasil belajar Siswa pada kondisi awal dan Siklus 1}

\begin{tabular}{|c|c|c|c|c|}
\hline No. & Kategori Nilai & $\begin{array}{c}\text { Kondisi Awal } \\
(\%)\end{array}$ & $\begin{array}{c}\text { Siklus 1 } \\
(\%)\end{array}$ & $\begin{array}{c}\text { Siklus 2 } \\
(\%)\end{array}$ \\
\hline
\end{tabular}




\begin{tabular}{|l|l|l|l|l|}
\hline 1 & Belum Tuntas: $<$ KKM & 71,88 & 46,875 & \\
\hline 2 & Tuntas: $=/>$ KKM & 28,12 & 53,125 & \\
\hline
\end{tabular}

Kalau kita lihat pada tabel di atas menunjukkan bahwa hasil belajar siswa mengalami peningkatan setelah dilakukan tindakan. Persentase siswa yang belum tuntas mengalami penurunan dari kondisi awal ke siklus 1 (dari 71,88\% menjadi 46,874\%. Persentase siswa yang sudah tuntas mengalami kenaikan dari kondisi awal ke siklus 1 (dari 28,12\% menjadi 53,125\%). Indikator keberhasilan dari PTK ini adalah, PTK dikatakan sudah berhasil jika persentase siswa yang nilai hasil belajarnya sudah tuntas mencapai minimal 84,38\%. Dari tabel menunjukkan bahwa persentase siswa yang nilainya tuntas baru mencapai 53,125\%, maka PTK harus dilanjutkan pada siklus 2 .

\section{Refleksi siklus 1}

Adapun hasil dari kegiatan refleksi itu adalah sebagai berikut: a). Pendidik harus menggunakan media, alat peraga untuk menjelaskan tugas, yang tepat untuk memudahkan siswa dalam menerima pelajaran. b) Pendidik harus memperbaiki cara melakukan evaluasi tingkat unjuk kerja siswa, yakni dengan cara memberikan reward agar siswa termotivasi. c) Pendidik harus memberikan contoh langkah-langkah penting dalam menyelesaika tugas/soal. d) Pendidik harus memperbaiki cara memberikan umpan balik, yakni dengan cara menunjukkan secara detail kesalahan-kesalahan yang dilakukan siswa beserta solusinya, seraya memberikan motivasi bahwa kesalahan bukanlah cela, tetapi sebagai cara untuk memotivasi diri untuk belajar kembali. e) Pendidik harus memeriksa dan jika perlu memberikan umpan balik atas hasil kerja siswa. f) Pendidik harus bisa memberikan tugas yang menantang sekaligus tidak membuat siswa putus asa. Caranya adalah tugas yang diberikan dari yang ringan sampai yang sulit. Kalau pun mereka tidak bisa melakukan yang sulit, tetapi masih bisa melakukan yang mudah sehingga tidak membuat siswa putus asa. g) Pendidik secara umum harus mengoptimalkan langkahlangkah tindakan yang mendapat skor Kurang (1) dan skor Baik (2) menjadi skor yang Sangat Baik (3).

\section{Siklus II \\ Perencanaan Tindakan siklus 2}

Rencana tindakan pada siklus 2 untuk memperbaiki motivasi dan hasil belajar siswa dibuat Rencana Pelaksanaan Pembelajaran (RPP) untuk tiga kali pertemuan (RPP lengkap terlampir). RPP dikembangkan dengan menggunakan model pembelajaran Kooperatif Jigsaw sama dengan pada siklus 1. Kompetensi Dasar yang akan diajarkan dalam RPP ini adalah KD2. RPP ini akan diimplementasikan pada pertemuan pertama, kedua dan ketiga, yakni hari Sabtu, tanggal 4, 11, 18 April, tahun 2020. Secara umum langkah-langkah pembelajaran pada siklus 2 ini sama dengan pada siklus 1. Perbedaannya adalah pada tindakan pada setiap langkah dioptimalkan sesuai hasil refleksi pada siklus 1. Yang diperbaiki adalah sebagai berikut: 1) Pendidik harus menggunakan media, alat peraga untuk menjelaskan tugas, yang tepat untuk memudahkan siswa dalam menerima pelajaran. 2) Pendidik harus memperbaiki cara melakukan evaluasi tingkat unjuk kerja siswa, yakni dengan cara memberikan reward agar siswa termotivasi. 3) Pendidik harus memberikan contoh langkah-langkah penting dalam menyelesaika tugas/soal. 4) Pendidik harus memperbaiki cara memberikan umpan balik, yakni dengan cara menunjukkan secara detail kesalahan-kesalahan yang dilakukan siswa beserta solusinya, seraya memberikan motivasi bahwa kesalahan bukanlah cela, tetapi sebagai cara untuk memotivasi diri untuk belajar kembali. 5) Pendidik (peneliti) harus memeriksa dan jika perlu memberikan umpan balik atas hasil kerja siswa. 6) Pendidik harus bisa memberikan tugas yang menantang sekaligus tidak membuat siswa putus asa. Caranya adalah tugas yang diberikan dari yang ringan sampai yang sulit. Kalau pun mereka tidak bisa melakukan yang sulit, tetapi masih bisa melakukan yang mudah sehingga tidak membuat siswa putus asa. 7) Pendidik secara umum harus mengoptimalkan langkah-langkah tindakan yang mendapat skor Kurang (1) dan skor Baik (2) menjadi skor yang Sangat Baik (3). 


\section{Pelaksanaan Tindakan siklus 2}

Berdasarkan hasil observasi yang dilakukan oleh tiga observer (teman sejawat), dengan menggunakan lembar observasi (terlampir) dalam tiga kali pertemuan, yakni pertemuan pertama hari Sabtu, tanggal 4 Maret tahun 2020, pertemuan kedua pada hari Sabtu, tanggal 11 Maret tahun 2020, pertemuan ketiga pada hari Sabtu, tanggal 18 Maret tahun 2020, ditemukan bahwa proses pembelajaran berlangsung sebagai berikut: 1) Pertemuan pertama, secara umum sudah sesuai dengan rencana tindakan (RPP pertemuan 1). Berdasarkan observasi menurut 3 observer dan hasil analisis data diketahui bahwa pembelajaran sudah berlangsung sangat baik. 2) Pertemuan kedua Secara umum sudah sesuai dengan rencana tindakan (RPP pertemuan ke 2). Berdasarkan observasi menurut 3 observer dan hasil analisis data diketahui bahwa pembelajaran sudah berlangsung sangat baik. 3) Pertemuan ketiga, secara umum sudah sesuai dengan rencana tindakan (RPP pertemuan ke 3). Berdasarkan observasi menurut 3 observer dan hasil analisis data diketahui bahwa pembelajaran sudah berlangsung sangat baik.

\section{Hasil Penelitian dan Refleksi siklus 2 Motivasi}

Menurut observer 1 didapatkan data bahwa, persentase siswa yang memiliki motivasi rendah ada $0 \%$, sedang ada $1250 \%$, dan tinggi $87.50 \%$. Menurut observer 2 didapatkan data bahwa persentase siswa yang memiliki motivasi rendah ada $0 \%$, sedang $12.50 \%$ dan tinggi $87.50 \%$. Menurut observer 3 didapatkan data bahwa persentase siswa yang memiliki motivasi rendah ada $0 \%$, sedang $15,62 \%$, dan tinggi $84,50 \%$. Kalau dirata-rata dari tiga observer tersebut diperoleh data bahwa persentase siswa yang motivasinya rendah ada $0 \%$, sedang $13,54 \%$ dan tinggi $86,46 \%$. Kalau dibandingkan dengan motivasi siswa pada kondisi awal dan siklus 1 adalah sebagai berikut:

Tebel 3. Motivasi Siswa Kondisi Awal siklus 1 dan siklus 2
\begin{tabular}{|l|l|l|l|l|}
\hline No. & $\begin{array}{c}\text { Kategori } \\
\text { Motivasi }\end{array}$ & $\begin{array}{c}\text { Kondisi } \\
\text { Awal }(\%)\end{array}$ & $\begin{array}{c}\text { Siklus } 1 \\
(\%)\end{array}$ & $\begin{array}{c}\text { Siklus } 2 \\
(\%)\end{array}$ \\
\hline 1 & Tinggi & 6,25 & 23,96 & 86,46 \\
\hline 2 & Sedang & 21,88 & 37,50 & 13,54 \\
\hline 3 & Rendah & 71,88 & 38,54 & 0 \\
\hline
\end{tabular}

Tabel di atas menunjukkan bahwa motivasi siswa dari kondisi awal, siklus 1, siklus 2 mengalami peningkatan. PTK sudah dikatakan berhasil, persentase siswa yang motivasinya dengan kategori rendah sudah mencapai mencapai $0 \%$.

\section{Hasil Belajar}

Rata-rata nilai siklus 2 ini mengalami kenaiakn dibanding di siklus 1, yakni 68 menjadi 75. Jika dipersentase berdasarkan kategori belum tuntas $(<\mathrm{KKM})$ dan tuntas $(=/>\mathrm{KKM})$ adalah sebagai berikut (lihat KKM KD2 = 68): Persentase Belum Tuntas: 4/32 x 100\% $=12.50 \%$, Persentase Sudah Tuntas: $28 / 32$ x 100\% $=87.50 \%$

Tabel 4. Hasil belajar Kondisi awal, siklus 1 dan 2

\begin{tabular}{|l|l|r|r|r|}
\hline No. & \multicolumn{1}{|c|}{ Kategori Nilai } & $\begin{array}{c}\text { Kondisi } \\
\text { Awal (\%) }\end{array}$ & $\begin{array}{c}\text { Siklus } \\
\mathbf{1}(\mathbf{\%})\end{array}$ & $\begin{array}{c}\text { Siklus 2 } \\
(\mathbf{\%})\end{array}$ \\
\hline 1 & Belum Tuntas (<KKM) & 71,88 & 46,88 & 12,50 \\
\hline 2 & Tunas (> KKM) & 28,12 & 53,12 & 87,50 \\
\hline
\end{tabular}

Kalau kita lihat contoh tabel di atas menunjukkan bahwa hasil belajar siswa mengalami peningkatan setelah dilakukan tindakan. Persentase siswa yang belum tuntas mengalami penurunan dari siklus 1 ke siklus 2 (dari $46,88 \%$ menjadi $12.5 \%$. Persentase siswa yang sudah tuntas mengalami kenaikan dari siklus 1 ke siklus 2 (dari 53,12\% menjadi 87.50\%). Indikator keberhasilan PTK ini adalah, bahwa PTK ini dikatakan berhasil jika persentase siswa yang nilai 
hasil belajarnya sudah tuntas mencapai minimal 84,38\%. Dari tabel menunjukkan bahwa persentase siswa yang nilainya tuntas sudah mencapai $87.50 \%$, maka PTK sudah berhasil (tidak dilanjutkan pada siklus 3).

\section{Refleksi siklus 2}

Dari analisis data motivasi siswa menunjukkan dari kondisi awal, siklus 1 dan siklus 2 mengalami peningkatan yang cukup berarti. Pada siklus 2 persentase siswa yang motivasinya rendah sudah mencapai 0\%. Dari analisis data hasil belajar siswa menunjukkan dari kondisi awal, ke siklus 1 dan siklus 2 mengalami peningkatan yang cukup berarti. Persentase hasil belajar pada siklus 2 sudah mencapai target (indikator kinerja) bahkan melebihi. Jadi sudah mencapai target seperti yang ditetapkan pada indikator kinerja PTK ini. Dari analisis data menunjukkan proses pembelajaran yang dilakukan pada siklus 2 jauh lebih baik dibanding pada siklus 1. Secara umum proses pembelajaran pada siklus 2 kategorinya sangat bagus. Dari datadata tersebut menunjukkan bahwa tindakan yang dilakukan oleh pendidik terus mengalami perbaikan dan sudah mencapai sesuai yang ditargetkan. Maka siklus PTK ini selesai pada siklus 2 saja.

\section{Pembahasan}

Motivasi dan hasil belajar siswa sangat ditentukan oleh model pembelajaran yang digunakan oleh guru selama proses pembelajaran berlangsung. Proses pembelajaran yang monoton, tentu tidak akan berdampak bagi motivasi dan keberhasilan siswa dalam mencapai hasil belajar yang tinggi. Peningkatan hasil belajar bisa ditingkatkan ketika proses pembelajaran yang berlangsung melibatkan siswa dalam berbagai bentuk dan langkah kegiatan. Model Kooperatif Jigsaw merupakan salah satu model pembelajaran yang memfasilitasi hal tersebut. Tahap-tahap belajar Kooperatif Jigsaw menunjukkan proses pembelajaran (kegiatan) yang bervariasi. Secara umum langkah-langkah tersebut dapat memberikan dampak terhadap peningkatan motivasi dan hasil belajar siswa. Hasil penelitian ini menunjukkan bahwa setiap langkah Kooperatif Jigsaw harus dilakukan lebih kreatif dan inovatif. Artinya, pendidik memiliki peran sentral dalam pembelajaran. Pendidik harus bisa merancang secara kreatif pada setiap langkah model Kooperatif Jigsaw ini. Hal ini dapat dilihat sebagai berikut:

\section{Siklus Pertama}

Pada siklus ini pendidik telah menerapkan langkah-langkah model Kooperatif Jigsaw sesuai dengan prosedur. Tetapi pada pelaksanaannya belum optimal karena ada beberapa langkah yang dilakukan memerlukan kreativitas dan inovasi, yakni (a) penggunaan media pembelajaran dalam rangka untuk mempermudah pemahaman siswa, (b) Mengevaluasi tingkat unjuk kerja siswa (C) Memberikan contoh langkah-langkah penting dalam menyelesaika tugas/soal (d) Memberikan umpan balik (yang bersifat korektif) atas kesalahan siswa dan mendorongya untuk menjawab dengan benar setiap tugas yang diberikan (e) Memeriksa dan jika perlu memberikan umpan balik atas hasil kerja siswa. Tetapi secara umum, pada siklus ini hasilnya lebih baik dibanding dengan kondisi awal dari aspek motivasi dan hasil belajar siswa. Setelah dilakukan diskusi refleksi, kekurangan-kekurangan tersebut diperbaiki, yakni dengan (1) Pendidik (peneliti) harus menggunakan media, alat peraga untuk menjelaskan tugas, yang tepat untuk memudahkan siswa dalam menerima pelajaran (2) Pendidik (peneliti) harus memperbaiki cara melakukan evaluasi tingkat unjuk kerja siswa, yakni dengan cara memberikan reward agar siswa termotivasi (3) Pendidik (Peneliti) harus memberikan contoh langkah-langkah penting dalam menyelesaika tugas/soal (4) Pendidik (peneliti) harus memperbaiki cara memberikan umpan balik, yakni dengan cara menunjukkan secara detail kesalahan-kesalahan yang dilakukan siswa beserta solusinya, seraya memberikan motivasi bahwa kesalahan bukanlah cela, tetapi sebagai cara untuk memotivasi diri untuk belajar kembali (5) Pendidik ( peneliti ) harus memeriksa dan jika perlu memberikan umpan balik atas hasil kerja siswa (6) Pendidik (peneliti) harus bisa memberikan tugas yang menantang sekaligus tidak membuat siswa putus asa. Caranya adalah tugas yang diberikan dari yang ringan sampai yang 
sulit. Kalau pun mereka tidak bisa melakukan yang sulit, tetapi masih bisa melakukan yang mudah sehingga tidak membuat siswa putus asa (7) Pendidik (peneliti) secara umum harus mengoptimalkan langkah-langkah tindakan yang mendapat skor Kurang (1) dan skor Baik (2) menjadi skor yang Sangat Baik (3).

Siklus Kedua

Dari analisis data motivasi siswa menunjukkan dari kondisi awal, siklus 1 dan siklus 2 mengalami peningkatan yang cukup berarti. Pada siklus 2 persentase siswa yang motivasinya rendah sudah mencapai $0 \%$. Jadi sudah mencapai target seperti yang ditetapkan pada indikator kinerja PTK ini. Untuk lebih jelas dapat dilihat pada tabel 5 dan gambar 2 berikut ini.

Tabel 5. Motivasi Siswa Kondisi Awal Siklus 1 dan Siklus 2

\begin{tabular}{|l|l|l|c|l|}
\hline No. & Kategori Motivasi & Kondisi Awal & Siklus 1 & \multicolumn{1}{|c|}{ Siklus 2 } \\
\hline 1 & Tinggi & $6,25 \%$ & $23,96 \%$ & $86,46 \%$ \\
\hline 2 & Sedang) & $21,88 \%$ & $37,50 \%$ & $13,54 \%$ \\
\hline 3 & Rendah & $71,88 \%$ & $38,54 \%$ & $0 \%$ \\
\hline
\end{tabular}

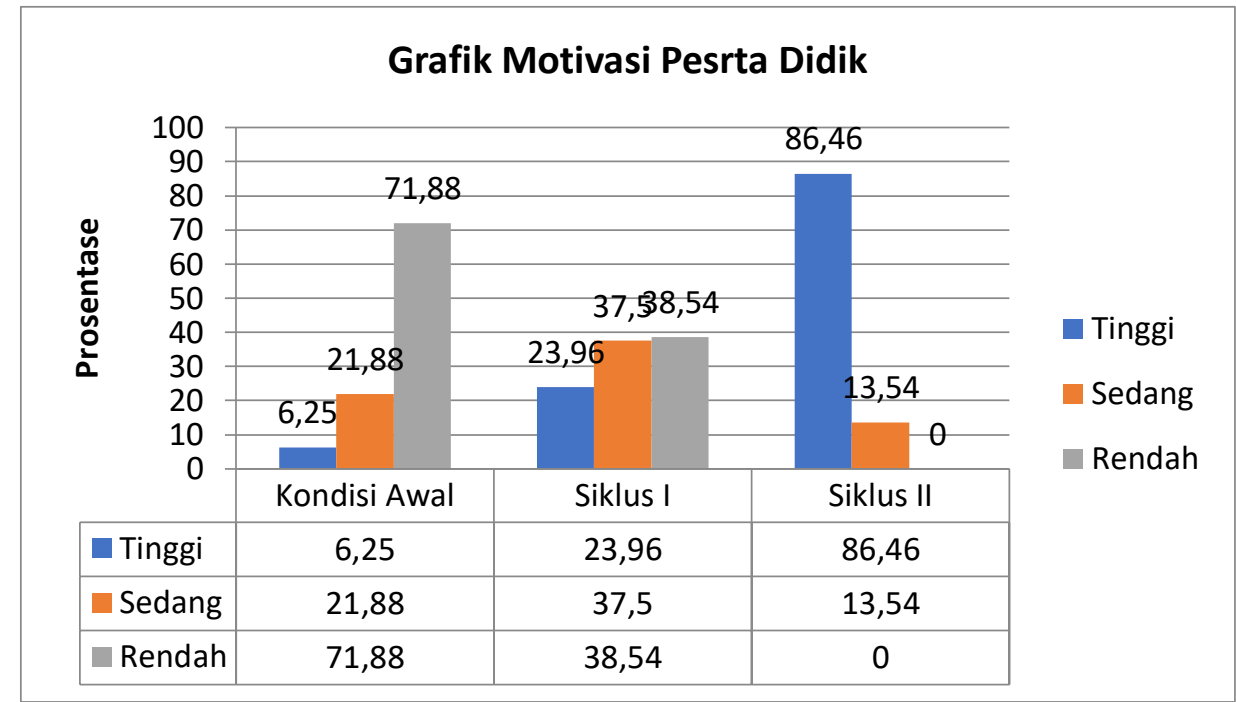

Gambar 2. Motivasi Grafik siswa dari kondisi awal, siklus 1 dan 2

Dari analisis data hasil belajar siswa menunjukkan dari kondisi awal, ke siklus 1 dan siklus 2 mengalami peningkatan yang cukup berarti. Persentase hasil belajar pada siklus 2 sudah mencapai target (indikator kinerja) bahkan melebihi. Data ini menunjukkan bahwa proses pembelajaran yang dilakukan oleh peneliti memberikan dampak bagi peningkatan terhadap hasil belajar siswa. Untuk lebih jelasnya dapat dilihat pada tabel 6 dan Gambar 3 berikut ini:

Tabel 6. Hasil belajar siswa kondisi awal, siklus 1 dan 2

\begin{tabular}{|l|l|l|l|l|}
\hline No. & \multicolumn{1}{|c|}{ Kategori Nilai } & Kondisi Awal & Siklus 1 & Siklus 2 \\
\hline 1 & Belum Tuntas $(<\mathrm{KKM})$ & $71,88 \%$ & $46,88 \%$ & $12,50 \%$ \\
\hline 2 & Tuntas $(=/>\mathrm{KKM})$ & $28,12 \%$ & $53,12 \%$ & $87,50 \%$ \\
\hline
\end{tabular}




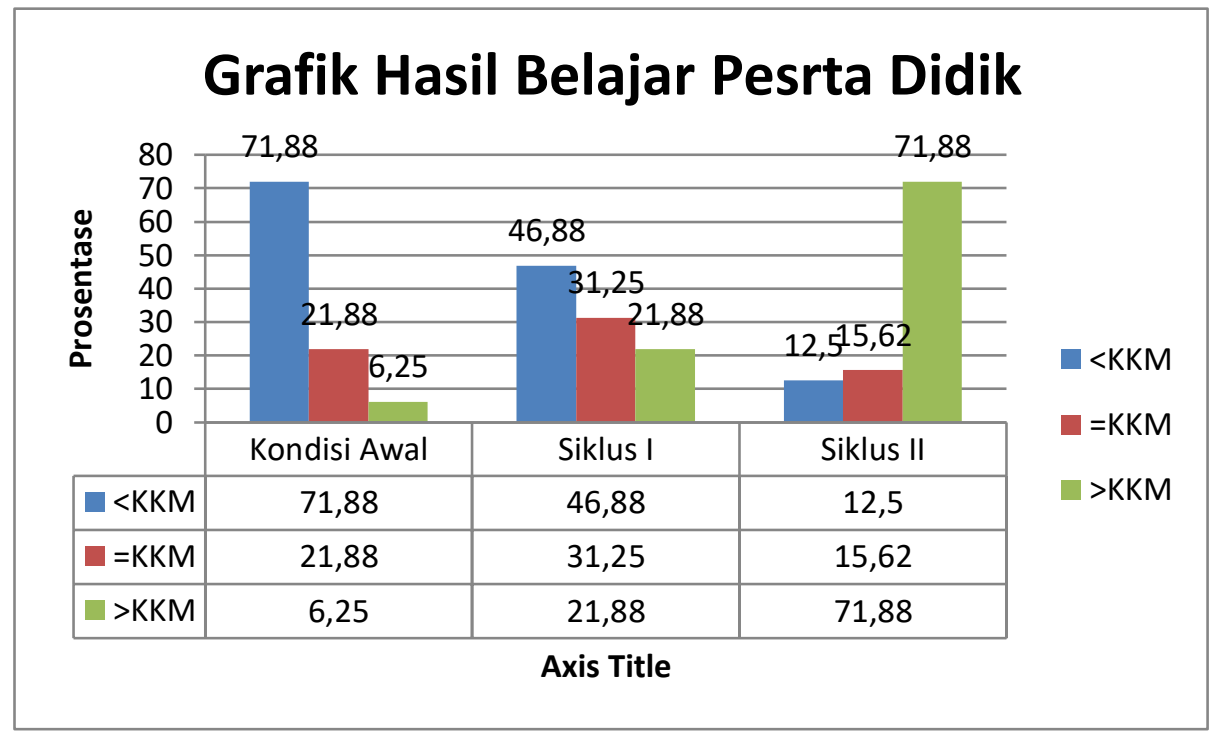

Gambar 3. Grafik Hasil Belajar Siswa

Dari analisis data menunjukkan proses pembelajaran yang dilakukan pada siklus 2 jauh lebih baik dibanding pada siklus 1 . Secara umum proses pembelajaran pada siklus 2 kategorinya sangat bagus. Dari data-data tersebut menunjukkan bahwa tindakan yang dilakukan oleh peneliti terus mengalami perbaikan dan sudah mencapai sesuai yang ditargetkan. Maka siklus PTK ini selesai pada siklus 2 saja.

Peneletian Tindakan kelas model pembelajaran kooperatif tipe jigsaw pernah juga dilakukan oleh Langlang, H., \& Khanafiyah, S. (2010) mengungkapkan bawah penerapan model pembelajaran kooperatif tipe Jigsaw mampu meningkatkan kemampuan pemecahan masalah pada siswa sekolah menengah pertama (SMP). GMA Widarta ( 2020 ) melakukan penelitian siswa kelas XI MIPA3 SMA Negeri 1 Marga semester 1 tahun pelajaran 2019/2020 menyimpulkan bahwa penerapan model pembelajaran kooperatif tipe jigsaw dapat meningkatkan motivasi dan hasil belajar kimia siswa dalam dua siklus.

\section{KESIMPULAN}

Berdasarkan hasil penelitian dan pembahasan di atas, dikemukakan bahwa setelah dilakukan tindakan dengan menggunakan model kooperatif jigsaw pada mata pelajaran Sejarah Kebudayaan Islam (SKI) kelas XI IPS 1 MAN 1 Cilacap terjadi perubahan pada motivasi dan hasil belajar siswa yang lebih baik. Perubahan ini nampak pada hasil observasi maupun posttes yang diperoleh pada pra-tindakan, pada tindakan siklus 1, dan pada tindakan siklus 2. Data perkembangan motivasi dan hasil belajar siswa pada tiap siklus yang mengalami kenaikan. Rata-rata motivasi pada sikus 1 yaitu 74,31\% menjadi $100 \%$ pada siklus ke 2 . Rata-rata hasil belajar pada siklus 1 yaitu 73,44\% menjadi 93,75\% pada siklus ke 2 . Melihat hasil penelitian ini dan setelah penulis sandingkan dengan beberapa hasil penelitian para peneliti lain sebagaimana dalam pembahasan di atas, penulis memberi saran keapada rekan-rekan guru untuk bisa menerapkan model kooperatif jigsaw dalam salah satu materi pembelajaran masingmasing.

\section{DAFTAR PUSTAKA}

Arikunto, Suharsimi. (2006). Penelitian Tindakan Kelas. Jakarta: PT Bumi, Aksara.

Hertiavi, M. D., Langlang, H., \& Khanafiyah, S. (2010). Penerapan model pembelajaran kooperatif tipe jigsaw untuk peningkatan kemampuan pemecahan masalah siswa SMP. Jurnal pendidikan fisika Indonesia, 6(1).

Kementerian Pendidikan Dan Kebudayaan Direktorat Jenderal Pendidikan Dasar Dan Menengah Direktorat Pembinaan Sekolah Menengah Pertama (2016). Panduan Pembelajaran Untuk Sekolah Menengaah Pertama, Jakarta 
Kementerian Pendidikan dan Kebudayaan Direktorat Jenderal Pendidikan Dasar dan Menengah Direktorat Pembinaan Sekolah Menengah Pertama Kompleks Kemdikbud, Gedung E, Lantai 15, 16, 17 Jalan Jenderal Sudirman, Senayan, Jakarta, 12070Telepon/Faksimile: 021-5725707, 5725681 http://ditpsmp.kemdikbud.go.id

Kurniasih, N. F. (2020). Upaya Meningkatkan Motivasi Belajar Siswa Melalui Model Pembelajaran Jigsaw Pada Mata Pelajaran Ski Di Min 1 Kota Bengkulu. Tarbiyah AlAwlad, 10(2).

Luthfiyah, U. (2018). Studi Eksperimen Pembelajaran Cooperative Learning Tipe Jigsaw Untuk Meningkatkan Hasil Belajar Siswa Pada Mata Pelajaran Sejarah Kebudayaan Islam Di Mi Nu Tarbiyatus Shibyan Jetak Kedungdowo Kaliwungu Kudus Tahun Pelajaran 2017/2018 (Doctoral Dissertation, Iain Kudus).

Mahfud AN ( 2017 ) Petunjuk Praktis Penelitian Tindakan Kelas ( PTK ) CV. Semarang : Rafi Sarana Perkasa

Normilasari, N., \& Haidawati, P. (2016). Upaya Meningkatkan Hasil Belajar IPA Dengan menggunakan Kombinasi Media Diorama dan Media Gambar Pada SDN 5 Langkai Palangkaraya Tahun Pelajaran 2015/2016. Tunas: Jurnal Pendidikan Guru Sekolah Dasar, 2(1), 11-15.

Qonita Alya (Cetakan 2009 edisi April 2011), Kamus Bahasa Indonesia Untuk Pendidikan Dasar. PT. Indahjaya Adipratama

Sinring, R. (2018). Efektivitas Metode Jigsaw dalam Meningkatkan Motivasi Belajar Sejarah Kebudayaan Islam Siswa di Kelas VIII MTs Darul Ulum Ath-Thahiriyah Paladang Kabupaten Pinrang (Doctoral dissertation, IAIN Parepare)

Suprihatin, S. (2017). Penggaruh Model Pembelajaran Jigsaw Terhadap Hasil Belajar Studi Masyarakat Indonesia Mahasiswa. PROMOSI: Jurnal Program Studi Pendidikan Ekonomi, 5(1).

Syarifuddin, A. (2011). Model pembelajaran cooperative learning tipe jigsaw dalam pembelajaran. Ta'dib: Jurnal Pendidikan Islam, 16(02), 209-226.

Pusat Bahasa Departemen Pendidikaan Nasional . (2002). Kamus Besar Bahasa Indonesia Edisi ketiga cetakan kedua. Jakarta : Balai Pustaka

Widarta, G. M. A. (2020). Penerapan model pembelajaran kooperatif tipe jigsaw untuk meningkatkan motivasi dan hasil belajar. Indonesian Journal of Educational Development, 1(2), 131-141. 